\title{
Temel Bileşenler Analizi ve Yanıt Yüzey Yöntemi Kullanılarak Gıda Sektöründe Çoklu Yanıtların Optimizasyonu
}

\author{
Deniz OZONUR ${ }^{1 *} \mathbb{D}$, Duygu KILIÇ², Hatice Tül Kübra AKDUR ${ }^{3}$, Hülya BAYRAK ${ }^{4}$
}

\author{
${ }^{1}$ Gazi Üniversitesi, Fen Fakültesi, İstatistik Bölümü, Ankara, Türkiye \\ ${ }^{2}$ Gazi Üniversitesi, Fen Bilimleri Enstitüsü, İstatistik Bölümü, Ankara, Türkiye \\ ${ }^{3}$ Gazi Üniversitesi, Fen Fakültesi, İstatistik Bölümü, Ankara, Türkiye \\ ${ }^{4}$ Gazi Üniversitesi, Fen Fakültesi, İstatistik Bölümü, Ankara, Türkiye \\ Geliş / Received: 20/11/2018, Kabul / Accepted: 13/05/2019
}

\section{$\ddot{\mathbf{O} z}$}

Temel bileşenler analizi büyük değişken kümesi içeren verinin boyutunu orijinal veride bilgi kaybına yol açmadan küçük kümeye indirger. Deneysel çalışmalarda çoklu korelasyona sahip yanıt değişkenler sıklıkla bulunmaktadır. Temel bileşenler analizi yanıt değişkenler kümesindeki bilginin çoğunu içeren bir genel yanıt değişken elde etmek için kullanılabilir. Genel yanıt değişken elde edildikten sonra, birkaç bağımsız değişkenden etkilenen yanıt değişkeni optimize etmek için yanıt yüzey yöntemi kullanılabilir. Bu çalışmada fitik asit, fitat fosforu, toplam fosfor gibi korelasyonlu yanıt değişkenler içeren ekmek üretim işlemi verisine temel bileşenler analizi uygulanmıştır. Temel bileşenler analizi ile oluşturulan yeni yanıt değişkeni optimize etmek için yanıt yüzey yöntemi uygulanmış ve en uygun koşullar elde edilmiştir.

Anahtar Kelimeler: Çoklu yanıt, temel bileşenler analizi, yanıt yüzey yöntemi, ekmek üretimi

\begin{abstract}
Multi Response Optimization in Food Industry Using Principal Component Analysis and Response Surface Methodology

Abstract

Principal component analysis reduces the dimensionality of data containing a large set of variables to small set without loosing the most important information in the original data set. Multiple correlated response variables are often included in experimental studies. Principal component analysis can be used to generate one overall response variable that contains most of the information in the set of response variables. After obtaining one overall response variable of the experimental design model, response surface method can be used to optimize the new response variable which is influenced by several independent variables. In this paper principal component analysis is applied to data of bread production process which contains correlated response variables such as phytic acid, phytate phosphor, total phosphor. Response surface method is conducted to optimize new response generated by principal component analysis and the optimum conditions are obtained.
\end{abstract}

Keywords: Multiple response, principal component analysis, response surface method, bread production

\section{Giriş}

Deneyler, araştırmayı yapan kişiler tarafından bir sistemi ya da belirli bir süreci tanımlamak ve anlamak için kullanılırlar. Gıda, sağlık, kimya gibi bir çok bilim alanında ve endüstride sıklıkla kullanılan deney tasarımı, ilgilenilen faktörler ve bağımlı (yanıt) değişken arasındaki etkileşimi tahmin eden popüler bir tekniktir. $\mathrm{Bu}$ alanlarda teknolojinin de gelişmesi ile birlikte karmaşıklaşan üretim süreçlerinde çoklu yanıt problemi ortaya çıkmaya başlamıştır. Bu çoklu yanıtların birlikte optimize edilmesi sırasında hedef; ürün kalitesini artırmak, maliyeti düşürmek veya parametre optimizasyonunu elde etmektir. Yanıt yüzey yöntemi (YYY) aracılığı ile bir yüzeyin veri setine uydurulması, optimum faktör 
düzeylerinin belirlenmesi, yanıt değişkeni ile kontrol değişkeni arasındaki ilişkiyi temsil eden bir denklem elde edilebilir. Yüzey grafiğini belirlemek ve optimal girdiyi karakterize etmek için kontur grafiği kullanılır. Birden fazla yanıt algılandıktan sonra parametre optimizasyonu, üst üste kontur çizimleri gözlemlenerek elde edilir (Shadkam and Bijari, 2015). Yanıt sayısında oluşan artış, yanıt yüzey denklemlerini ve yüzey sayılarını da artıracaktır. $\mathrm{Bu}$ durum karmaşıklığa yol açacaktır. Çoklu yanıt modellerinde optimal girdileri tanımlamak, birden fazla çıktının da aynı anda optimize edilmesini gerektirdiği durumlarda zordur. Temel bileşenler analizi (TBA) yöntemi ile bir dizi orijinal yanıt, bir dizi ilişkili olmayan bileşene dönüştürülebilir. Bu yönüyle çoklu yanıt problemleri için tasarım parametrelerinin optimalliğinin belirlemesinde ortaya çıkan karmaşıklık en aza indirgenmektedir (Tong and Su, 1997).

TBA yönteminden farklı olarak, veri zarflama analizi (VZA) veya bulanık mantık tekniği kullanılarak da çoklu yanıtlar tek bir yanıt haline getirilebilir. Çoklu yanıt probleminin çözümünde kullanılan bir diğer yöntem Derringer-Suich (1980) yöntemidir (Derringer and Suich, 1980). Bu yöntemde problemi optimize etmek için istenebilirlik (desirability) fonksiyonu kullanmışlardır. Khuri ve Conlon (1981), çok terimli regresyon modeline dayanan bir yöntem önermişlerdir. Tong ve Su (1997), temel bileşen analizi yardımı ile problemi çözmeye çalışmışlardır. Köksoy (2005), ikili yanıt probleminde bağımlılık yapısını incelemiştir. Tsai vd. (2010) çoklu yanıt problemini çözmek için yanıt yüzey yöntemi ile veri zarflama analizini içeren yeni bir yöntem ortaya koymuşlardır. Sahu vd. (2013) AISI D2 çeliğinin elektrik boşaltma işleminde çoklu yanıtların optimizasyonu için veri zarflama analizi yaklaşımını önermişlerdir. DiazGarciaand ve Bashiri (2014), çoklu yanıt problemini stokastik optimizasyon olarak modellemişlerdir. Shadkam ve Bijari (2015), çoklu yanıt problemi için yanıt yüzey yöntemi, veri zarflama analizi ve Cuckoo algoritması kullanmışlardır. Tai vd. (1992) sorunu çözmek için her yanıta bir ağırlık vererek çözüme ulaşmaya çalışmıştır. Pignatiello (1993), çoklu yanıt problemini optimize etmek için beklenen kayıp fonksiyonunu oluşturmak için hedeften sapma ve sapma karesi kullanmışlardır. Ebegil vd. (2017) çoklu yanıtların optimize edilmesinde yanıt yüzey yöntemi ve veri zarflama analizinin bir kombinasyonunu kullanmışlardır. Bu çalışmada, korelasyonlu yanıtlar içeren ekmek üretim verisinde tek bir yanıt elde etmek amacıyla TBA kullanılmıştır ve oluşturulan yeni yanıtın optimizasyonu için YYY uygulanmıştır.

\section{Materyal ve Metot}

\subsection{Temel bileşenler analizi}

TBA, aralarında ilişki olan ve çok sayıda değişkenden oluşan birçok değişkenli veri yapısını, bu değişkenlerin doğrusal fonksiyonları şeklinde daha az sayıda ve birbirleri ile ilişkisiz yeni değişkenlere dönüştüren çok değişkenli bir istatistiksel analiz tekniğidir. TBA, çok değişkenli istatistiksel çıkarımlarda kullanılan son derece popüler bir tekniktir. Boyut indirgemesinde ve değişkenler arasında ilişki olması durumunda kullanılır. Ayrıca orijinal değişkenlerin doğrusal kombinasyonları ile varyanskovaryans yapısının açıklanmasında kullanılır. Analizin amaçları şu şekilde siralanabilir:

i. Birbirleri ile ilişkili olan değişkenlerden, ilişkisiz yeni değişkenler türetmek. Bir diğer ifade ile çoklu bağlantı sorununu gidermek. 
ii. Değişken sayısını azaltarak boyut indirgemek.

iii. Zaman, maliyet ve güncelliği koruma noktasında avantaj sağlamak.

iv. Birbirleri ile ilişkili olan değişkenlerin oluşturduğu başlangıç sistemine ait çok değişkenli bir veriyi, birbirleri ile ilişkisiz değişkenlerin oluşturduğu temel bileşen skorları verisine dönüştürmek. Analizde, karşılıklı bağımlılık yapısı gösteren, adet değişken; doğrusal, dikey ve birbirinden bağımsız olma özelliklerini taşıyan tane yeni değişkene dönüştürülmektedir.

TBA farklı analizler için yardımcı bir teknik olarak kullanılmaktadır. TBA'da sayıda başlangıç değişkenine karşılık elde edilen sayıda temel bileşenin her biri, orijinal değişkenlerin doğrusal bir bileşimidir. Dolayısıyla, her bir temel bileşen bünyesinde tüm değişkenlerden belirli oranda bilgiyi barındırır. $\mathrm{Bu}$ özelliği sayesinde TBA, boyutlu veri seti yerine, ilk önemli temel bileşenin kullanılması yoluyla boyut indirgemesi sağlayabilmektedir. İlk temel bileşen toplam varyansın büyük kısmını açıklıyorsa, geriye kalan temel bileşen ihmal edilebilir (Hair vd., 2009).

TBA'nin sadece ana bileşenler ile orijinal yanıtlar arasında anlamlı bir ilişki gözlemlendiğinde uygulanabileceğinin belirtilmesi önemlidir. Bu durumda, orijinal yanıt değişkenleri, veri kümesindeki maksimum varyansı açıklayabilecek bir ana bileşenin skor değerleri ile değiştirilebilir. İlk birkaç ana bileşenin skoru, yanıt yüzey yöntemi kullanılarak optimizasyon için yeni yanıt değişkeni olarak ele alınabilir. Çoklu yanıt yüzey stratejisinde, deneysel tasarımla birlikte temel bileşenler analizi kullanıldığında bağımlı değişkenlerin karmaşıklığı en aza indirilmektedir.

\subsection{Temel bileșenlerin elde edilmesi}

Başlangıçta $p$ tane değişken $X_{1}, \ldots, X_{p}$ olduğu varsayılsın. $\mathrm{Bu}$ değişkenlerin oluşturduğu sistem ise $\underline{X}^{\prime}=\left(X_{1}, \ldots, X_{p}\right)$ değişkenler vektörü ile gösterilsin. $E\left(\underline{X}^{\prime}\right)=\underline{\mu}$ ve $\operatorname{Cov}\left(\underline{X}^{\prime}\right)=\sum$ olmak üzere; $\mu: p x 1$ boyutlu kitle ortalama vektörü ve $\sum:$ xxp boyutlu kitle ortalama varyanskovaryans matrisini ifade eder. Temel bileşenler aşağıda gösterildiği gibidir:

$$
\begin{aligned}
& Y_{1}=a_{11} X_{1}+a_{12} X_{2}+\ldots+a_{1 p} X_{p} \\
& Y_{2}=a_{21} X_{1}+a_{22} X_{2}+\ldots+a_{2 p} X_{p} \\
& \vdots \\
& Y_{p}=a_{p 1} X_{1}+a_{p 2} X_{2}+\ldots+a_{p p} X_{p}
\end{aligned}
$$

Burada $Y_{1}, \ldots, Y_{p} \quad$ temel bileşenler, $a_{11}, a_{21}, \ldots, a_{p p}$ sabit sayılardır ve temel bileşen yüklerini gösterirler. Temel bileşen yükleri, temel bileşenlerin değişkenler üzerindeki varyans katkısını gösteren ağırlıklardır.

\subsection{Yanıt yüzey yöntemi}

YYY'nde ilgili herhangi bir yanıtın yanıt yüzeyi bir amaç fonksiyonu olarak seçilir. Diğer yanıt yüzeyleri ise birer sınır fonksiyonları olurlar. Bu yönüyle yanıt yüzey yöntemi, matematiksel ve istatistiksel tekniklerin bir arada kullanıldığı bir optimizasyon problemidir. Bu teknikte temel amaç, çeşitli süreç parametrelerinden etkilenen yanıt yüzeyini optimum yapmaktır. $\mathrm{Bu}$ yöntem başta gıda olmak üzere, sağlık, farmakoloji, savunma sanayisi, kimya ve mühendislik gibi birçok alanda kullanılmaktadır. YYY'nde kullanılan adımlar Şekil 1'de özetlenmiştir. 


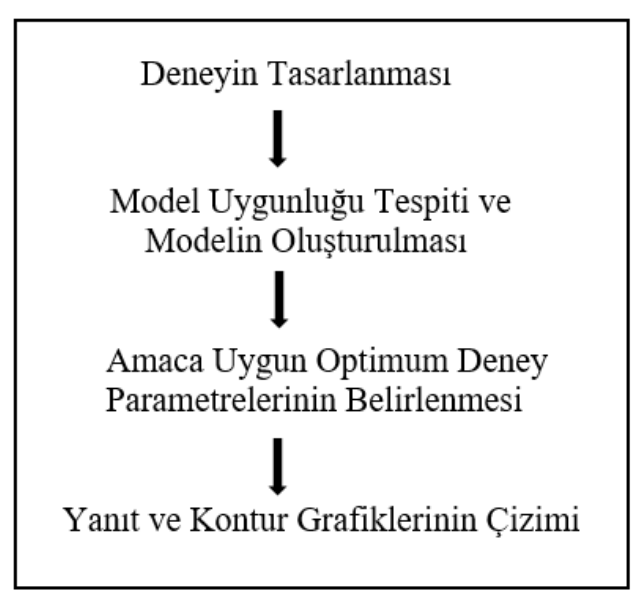

Şekil 1. Yanıt yüzey yönteminde kullanılan adımlar

YYY'nde model çoklu regresyon analizi yardımıyla oluşturulur. Bir faktörün ana etkisinin veya etkileşim etkisinin yanıt değişkenin değerlerinde ne derece önemli bir etkiye sahip olduğuna regresyon katsayıları yardımıyla karar verilir. YYY'nde ilk adım yanıt değişskeni üzerinde etkisi olduğu düşünülen faktörleri ve sahip oldukları düzeyleri belirlemektir (K1lıç vd., 2018). Bu adımdan sonra, deney tasarımı, regresyon ve optimizasyon teknikleri iç içe kullanılır. İkinci dereceden bir model Eşitlik 1'de gösterilmiştir.

$Y=\beta_{0}+\sum_{i=1}^{k} \beta_{i} X_{i}+\sum_{i=1}^{k} \beta_{i i} X_{i}^{2}+\sum_{i=1}^{k-1} \sum_{j=i+1}^{k} \beta_{i j} X_{i} X_{j}+\varepsilon$

Burada $Y ;$ yanıt değişken, $X_{i}$ ve $X_{i}^{2}(i=1,2, \ldots, k) ; \quad$ bağımsız değişkenler, $\beta_{0}, \beta_{i}, \beta_{i i}(i=1, \ldots, k), \beta_{i j}(i=1, \ldots, k-1$; $j=i+1, \ldots, k)$; regresyon katsayıları ve $\varepsilon$; rastgele hata terimidir.

Yanıt yüzey grafiği ikiden fazla faktörün düzeylerinin yanıt değişkeni üzerine etkisinin üç boyutlu olarak gösteriminde kullanılan grafiklerdir. Eğer ikiden fazla faktör varsa, diğer faktörlerin düzeyleri sabitlenerek asıl ilgilenilen faktörlerin değerlerini görmek de mümkündür. Faktörler ve yanıt değişkeni için oluşturulan model doğrusal bir model ise yanıt yüzey grafiği doğrusal bir şekil alırken, karesel terimler içeren bir model olduğunda eğrisel bir şekil alacaktır.

Genellikle yanıt yüzey problemlerinde, yanıtlar; en büyük en iyidir, en küçük en iyidir ve hedef en iyidir şeklindedirler. En küçük en iyidir yönteminde amaç; minimum yanıt değişkenine ulaşmaktır, en büyük en iyidir yönteminde amaç; maksimum yanıt değişkenine ulaşmaktır, hedef en iyidir yönteminde ise yanıt değişkenini hedef değer yapan kontrol değişkenlerinin düzeylerini veren $\chi^{2}$ (ki-kare) değerini bulmaktır. $\mathrm{Bu}$ yöntem diğer iki yönteme göre biraz daha karmaşıktır.

Yanıt yüzey çalışmalarının hedefleri; yanıt değişkeninin gelecekteki değerlerinin doğru olarak kestirebilmek için, yanıt değişkeni ile girdi değişkenleri arasındaki ilişkiyi belirleyecek uygun bir fonksiyonun (veya modelin) tespit edilmesi, problemin cinsine bağlı olarak en büyük veya en küçük yanıt değerinin araştırılması ve bu değeri sağlayabilecek girdi değişkenlerinin değerlerinin tespiti, bir yanıt sisteminin altında yatan mekanizmanın anlaşılmasına yönelik katkı beklentileri olarak sıralanabilir (Bayrak vd., 2010).

YYY'nde Merkezi Bileşik Deneme Düzeni (Central Composit Design-CCD) ve BoxBehnken Deneme Düzeni olmak üzere kullanılan başlıca iki teknik vardır. BoxBehnken deneme düzeni daha çok $k$ faktör sayısı olmak üzere $2^{k}$ denemelerde kullanılırken, CCD ise $3^{k}$ deneme düzeninde kullanılır. $\mathrm{Bu}$ çalışmada kullanılan ekmek üretim verisinin yapısı $3^{k}$ olduğundan analizlerde CCD kullanılmıştır. CCD en çok kullanılan yanıt yüzey tekniklerinin başında 
gelmektedir. Faktöriyel deneylerde ve kesirli faktöriyel deneylerde tercih edilmektedir.

YYY regresyon denklemi yardımıyla bir sürecin girdi ve çıktıları arasındaki ilişkiyi modelin bilinmesine gerek duymadan elde etmeyi sağlar. Yanıt sayısı kadar yanıt denklemi vardır ve o kadar yüzey ve kontur çizdirilebilir. $\mathrm{Bu}$ nedenle yanıt sayısının artmasıyla problemin çözümü ve yorumu karmaşık bir hal alabilir. TBA ile aralarında ilişki olan yanıtlar, daha az sayıya indirgenir ve aralarındaki ilişki ortadan kalkar. Geleneksel YYY'nde her bir yanitın tek tek hesaplanması ve yorumlanması zorluğunu ortadan kaldırması bu sayede zamandan tasarruf sağlaması yönüyle TBA ve YYY'nin birlikte kullanılması oldukça avantajı olmaktadır.

$\mathrm{Bu}$ çalışmada TBA ve YYY misır ekmeği üretim sürecinde kullanılmıştır. Mısır ve mısır ekmeği, iyi bir diyet lif, fenoliz madde ve antioksidan kaynağıdır. Fakat mısırda fazla miktarda fitik asit bulunmaktadır. Ayrıca buğday da olduğu gibi ögütme işlemi sırasında fitik asidin bir kısmı kepekle ayrılamamakta, tamamına yakın kismı misır ununa geçmektedir. Fitik asit, fosforun büyük bir kısmına fitat fosforu olarak bağlamakta, $\mathrm{Ca}, \mathrm{Zn}, \mathrm{Fe}$ gibi minerallerle kompleks oluşturmakta ve proteinlerle interaksiyona girerek bunların vücuda yarayışlılığını ortadan kaldırmaktadır. $\mathrm{Bu}$ nedenle fitik asidin beslenmede dikkate alınması gereken bir madde olduğu özellikle de çocuklar, hamileler, emziren anneler ve yaşlilar için önemli olduğu ifade edilmektedir (Özkaya vd., 2013). Bunun yani sıra, fitik asidin minerallerle birleşmesiyle oluşan fitatlar, protein emilimini de olumsuz yönde etkilemektedir. Fitik asit miktarı düşürülmüş g1da üretim metotlarından biri, fitik asit oranı düşük veya fitaz aktivitesi yüksek tahıl ıslah etmek, diğeri ise hammaddedeki fitik asiti çeşitli fiziksel ya da kimyasal yöntemlerle çözmek ya da uzaklaştırmaktır. Öğüterek tanenin kepeğinin uzaklaştırılması, fermantasyon, basınç altında pişirme, fitaz enzimi ilavesi, çimlendirme ve 1slatma, fitik asit miktarının düşürülmesinde kullanılabilecek en etkili fiziksel ve kimyasal yöntemlerdir. Fitik asitin proteinler üzerine de etkili olduğu ifade edilmektedir. Fitik asitin minerallerle kompleks oluşturmasıyla meydana gelen fitatlar proteolitik enzimler tarafından daha zor parçalanan fitat-protein kompleksleri oluşturarak protein emilimini olumsuz yönde etkilemektedir (Cheryan, 1980). Fitik asitin kolon kanserinin ve böbrek taşlarının oluşumunu azalttığı, kan kolesterolünü düşürdüğü literatürde bildirilmiştir (Empson vd., 1991). Ayrıca fitik asitin kemoterapide oldukça etkili olduğu ve lipaz aktivitesinde önemli azalmaya sebep olduğu belirtilmiştir (Knuckles, 1988). Ekmek üretim prosesinden sonra ekmekte kalan fitat oranı, kullanılan unun tipi, parçacık büyüklüğü, kullanılan maya miktarı ve tipi, fermantasyon süre ve sıcaklığ 1 , hamur pH'si gibi faktörlerden etkilenmektedir. Ekmek yapımı sırasında fitik asidin parçalanması en fazla fermantasyon aşamasında meydana gelmektedir. Hem beyaz ekmek ve tam un ekmeğinde, hem de çavdar ekmeğinde fermantasyon sırasında fitat oranının azaldı $\breve{g} 1$, parçalanmasının fermantasyonun uzatılmasıyla arttığı bildirilmiştir (Harland ve Harland, 1980). Fitik asit mineral maddeler ve proteinin emilimine engel olan besinsel bir ögedir. Son üründeki fitik asit ve fitat miktarı çeşitli fiziksel ve kimyasal işlemlerle düşürülebilmektedir. Ekmek yapımında en fazla fermantasyon aşamasında fitik asit kaybı söz konusudur. Kullanılan maya miktarı ve fermantasyon süresi fitik asitin azaltılmasında önemli faktörlerdir (Bilgiçli, 2002). Birçok ülkede olduğu gibi ülkemizde de insanların 
kalori, protein ve B grubu vitamin gereksinimlerinin karşılanmasında ekmeğin payı büyüktür. $O$ nedenle ekmeğin besin değerini etkileyen tüm faktörler, toplum sağlığı bakımından da önemlidir. Ekmek yapımında buğday dışında mısır, yulaf, çavdar gibi tahıllardan da yararlanılmaktadır. Misır ekmeğinde fazla miktarda bulunan fitik asit, bazı beslenme bozukluklarına neden olabilmektedir. $\mathrm{Bu}$ nedenle günümüzde ekmeğin fitik asit miktarı ve bunu etkileyen faktörler önem kazanmaktadır.

\section{Bulgular}

$\mathrm{Bu}$ çalışmada buğday unu, maya miktarı, fermantasyon süresi ve firın sicaklığının mısır ekmeğinin fitik asit, fitat fosforu ve toplam fosfor miktarı üzerindeki etkisi incelenmiştir. Bu amaçla 81 tane mısır ekmeği ele alınmıştır. Misır ununa farklı oranlarda buğday unu katılarak hazırlanan karışımlara farklı maya, fermantasyon ve pişirme süresi uygulayarak yapılan ekmeklerin fitik asit miktarları, fitat fosforu ve toplam fosfor miktarı ölçülmüsşür. $\mathrm{Bu}$ çalışmada kullanılan veri Ankara Üniversitesi Gıda Mühendisliği laboratuvarlarında yapılan deneysel çalışma sonucu elde edilen verilerdir.
Veride kullanılan değişkenlerin seçiminde uzman görüşü alınmıştır. Verinin analizinde uygulanan adımlar Şekil 2'de özetlenmiştir.

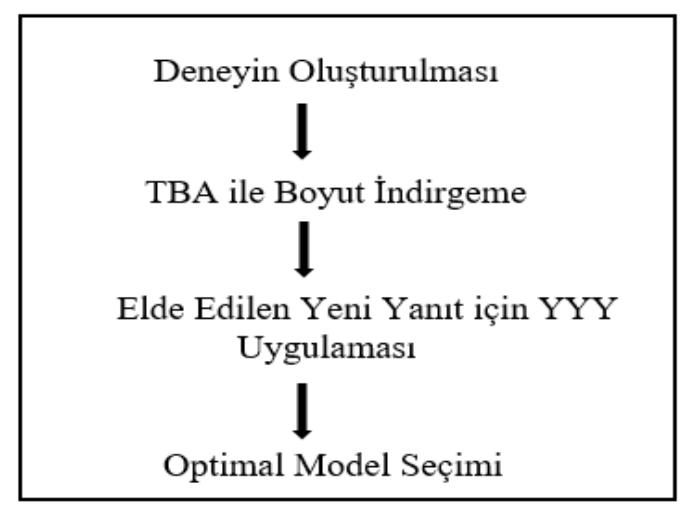

Şekil 2. Verinin optimizasyonunda

kullanılan adımlar

$\mathrm{Bu}$ çalışmada incelenen ekmek üretim sürecinde 3 yanıt (bağımlı) değişken; fitik asit $(\mathrm{mg} / 100 \mathrm{~g})$, fitat fosforu $(\mathrm{mg} / 100 \mathrm{~g})$, toplam fosfor $(\mathrm{mg} / 100 \mathrm{~g})$ ve 4 bağımsız değişken; buğday unu katma oranı (\%), maya miktarı (\%), fermantasyon süresi (dak) ve firın sicaklığ $1 \quad\left({ }^{\circ} \mathrm{C}\right)$ bulunmaktadır. Ekmek üretiminde kullanılan veri Tablo 1 'de gösterilmiştir (Kılıç, 2018). Bağımsız değişkenlerde kullanılan 0,1 ve 2 değerleri ilgili değişkenin sırasıyla düşük, orta ve yüksek düzeyini temsil etmektedir.

Tablo 1. Ekmek Üretim Verisi

\begin{tabular}{ccccccc}
\hline $\begin{array}{c}\text { Buğday } \\
\text { unu katma } \\
\text { oranı }\end{array}$ & $\begin{array}{c}\text { Maya } \\
\text { miktarı }\end{array}$ & $\begin{array}{c}\text { Fermantasyon } \\
\text { süresi }\end{array}$ & $\begin{array}{c}\text { Firın } \\
\text { sicakllğ } 1\end{array}$ & Fitik asit & Fitat fosforu & Toplam fosfor \\
\hline 0 & 0 & 0 & 0 & 1197,7 & 337,8 & 355,8 \\
0 & 0 & 0 & 1 & 1190,3 & 335,7 & 354,7 \\
0 & 0 & 0 & 2 & 1181,5 & 333,2 & 356,1 \\
. &. &. &. &. &. &. \\
. &. &. &. &. &. &. \\
. &. &. &. &. &. &. \\
1 & 0 & 0 & 0 & 1056,7 & 298 & 323,5 \\
1 & 0 & 0 & 1 & 1044,2 & 294,5 & 324,6 \\
1 & 0 & 0 & 2 & 1036,6 & 292,3 & 324,7 \\
. &. &. &. &. &. &. \\
. &. &. &. &. &. &. \\
. &. &. &. &. &. &. \\
2 & 0 & 0 & 0 & 868,2 & 244,8 & 291,5 \\
2 & 0 & 0 & 1 & 860,1 & 242,6 & 290,6 \\
2 & 0 & 0 & 2 & 851,4 & 240,1 & 291,7 \\
\hline
\end{tabular}


$\mathrm{Bu}$ veride bulunan çoklu yanıt problemi, TBA ile tek bir yanıtın olduğu probleme kolaylıkla dönüştürülebilir. Yanıt değişken boyutunu indirgeyebilmek için öncelikle verilerin TBA yöntemine uygunluğu Kaiser- Meyer- Olkin (KMO) ve Bartlett küresellik testi ile araştırılmış ve sonuçlar Tablo 2'de verilmiştir.

Tablo 2. Örneklem Büyüklüğünün yeterliliği için KMO testi

\begin{tabular}{cccc}
\hline KMO Örneklem Ölçüm Değer Yeterliliği & \multicolumn{3}{c}{ Bartlett Testi } \\
\hline 0,735 & Ki-Kare & s.d. & $p$ \\
& & &, 000 \\
\hline & 1436,833 & 3 & \\
\hline
\end{tabular}

KMO örneklem büyüklüğunün uygunluğu ile ilgilidir. 0,73 değeri bu veriler için TBA'nın uygulanabileceğini göstermektedir. Bartlett testi sonucu da $(p=0.000<0.05)$ anlamlı bulunmuştur.
Sonuçlar göz önüne alındığında verilerimiz TBA için uygundur. Uygunluk sağlandıktan sonra önemli temel bileşenlerin özdeğer ve açıklama yüzdeleri Tablo 3'teki gibi elde edilmiştir.

Tablo 3. Temel bileşenlerin özdeğer ve varyans yüzdeleri

\begin{tabular}{ccccccc}
\hline & \multicolumn{3}{c}{ Başlangıç Özdeğerleri } & \multicolumn{3}{c}{ Döndürülmüş Kareli Yüklerin Toplamı } \\
\cline { 2 - 6 } Bileşen & Toplam & Varyans(\%) & Kümülatif(\%) & Toplam & Varyans(\%) & Kümülatif(\%) \\
\hline 1 & 2,988 & 99,616 & 99,616 & 2,988 & 99,616 & 99,616 \\
2 & 0,012 & 0,384 & 100 & & & \\
3 & $3,023 \mathrm{E}-7$ & $1,008 \mathrm{E}-5$ & 100 & & & \\
\hline
\end{tabular}

Tablo 3'e göre 3 tane değișken kullanmak yerine 1 tane değişken kullanarak toplam varyansın \%99 unu açıklamak mümkün olmaktadır. $\mathrm{Bu}$ yeni oluşturulan değişken ile bağımlılık yapısı ortadan kalkmıştır ve TBA'nın amacı olan boyut indirgeme sağlanmıştır.

Tablo 4. CCD varyans analizi tablosu
Elde edilen yeni temel bileşen yeni yanıt değişkeni olarak ele alınır ve yeni yanıt değişkeni optimize etmek amaciyla YYY uygulanır. Tablo 4'te elde edilen yeni yanıt değişkenine ilişkin varyans analizi sonuçları gösterilmektedir.

\begin{tabular}{cccccc}
\hline Değişim & $\begin{array}{c}\text { Serbestlik } \\
\text { Derecesi }\end{array}$ & $\begin{array}{c}\text { Kareler } \\
\text { Toplamı }\end{array}$ & $\begin{array}{c}\text { Kareler } \\
\text { Ortalamas }\end{array}$ & $\mathrm{F}$ & $p$ \\
\hline Regresyon & 14 & 24.4783 & 1.7484 & 12.76 & $0.000^{*}$ \\
Lineer & 4 & 24.4363 & 6.1091 & 44.59 & $0.000^{*}$ \\
Karesel & 4 & 0.0337 & 0.0084 & 0.06 & 0.992 \\
İnteraksiyon & 6 & 0.0083 & 0.0014 & 0,01 & 1.000 \\
Hata & 15 & 2.0549 & 0.1370 & & \\
Toplam & 29 & 26.5332 & & & \\
\hline
\end{tabular}


Tablo 4'e göre lineer regresyon modelinin anlamlı olduğu $\quad(p=0.000<0.05)$ görülmektedir. Daha sonra regresyon analizi yapılarak değişkenlerin anlamlılığ incelenmiştir ve elde edilen sonuçlar Tablo 5'te özetlenmiştir. Burada $X_{1}$; buğday unu katma oranı, $X_{2}$; maya miktarı, $X_{3}$; fermantasyon süresi ve $X_{4}$; firın sıcaklığ değişkenlerini temsil etmektedir.

Tablo 5. CCD regresyon analizi tablosu

\begin{tabular}{ccc}
\hline Faktörler & $\mathrm{T}$ & $p$ değeri \\
\hline Sabit & 0.34 & 0.740 \\
$\mathrm{X}_{1}$ & -13.34 & $0,000^{*}$ \\
$\mathrm{X}_{2}$ & $-0,49$ & 0,628 \\
$\mathrm{X}_{3}$ & $-0,53$ & 0,609 \\
$\mathrm{X}_{4}$ & -0.44 & 0.668 \\
$\mathrm{X}_{1} * \mathrm{X}_{1}$ & $-0,47$ & 0,642 \\
$\mathrm{X}_{2} * \mathrm{X}_{2}$ & $-0,19$ & 0,854 \\
$\mathrm{X}_{3} * \mathrm{X}_{3}$ & -0.14 & 0,889 \\
$\mathrm{X}_{4} * \mathrm{X}_{4}$ & $-0,15$ & 0.886 \\
$\mathrm{X}_{1} * \mathrm{X}_{2}$ & -0.09 & 0,932 \\
$\mathrm{X}_{1} * \mathrm{X}_{3}$ & $-0,17$ & 0.865 \\
$\mathrm{X}_{1} * \mathrm{X}_{4}$ & $-0,12$ & 0.911 \\
$\mathrm{X}_{2} * \mathrm{X}_{3}$ & 0.05 & 0.957 \\
$\mathrm{X}_{2} * \mathrm{X}_{4}$ & 0.02 & 0.981 \\
$\mathrm{X}_{3} * \mathrm{X}_{4}$ & -0.08 & 0.938 \\
\hline
\end{tabular}

Tahmin edilen model;

$$
\begin{aligned}
\hat{y}= & 1,12541-1,01262 X_{1}-0,046377 X_{2} \\
& -0,036514 X_{3}-0,030253 X_{4}
\end{aligned}
$$

şeklindedir. $\mathrm{Bu}$ modelde parametrelerin anlamlılığına bakıldığında buğday unu katma oranın tek başına anlamlı bir faktör olduğu görülmektedir. Modele bağımsız değişken olarak sadece buğday unu katma oranı konularak tahmin edilen indirgenmiş model Eşitlik 2'de gösterilmiştir.

$\hat{y}=1,00494-1,00752 X_{1}$

Problemdeki yanıt değişken sayısını tek bir yanıt değişkene indirgemeden önce ve tek bir yanıt değişkene indirgedikten sonra oluşan açıklama yüzdeleri $\left(R^{2}\right)$ ve hata kareler ortalamaları (HKO) değerleri Tablo 6'da verilmiştir.

Tablo 6. TBA öncesi ve sonrasi $R^{2}$ ve HKO değerleri

\begin{tabular}{ccc}
\hline & $\begin{array}{c}\text { TBA öncesi } \\
\text { herbir değişken } \\
\text { için }\end{array}$ & $\begin{array}{c}\text { TBA sonras1 } \\
\text { yeni yanit } \\
\text { değişkeni için }\end{array}$ \\
\hline \multicolumn{3}{c}{ Fitik asit; } \\
$\% 92,60$ \\
Fitat fosforu; \\
$\% 92,12$ \\
Toplam fosfor; \\
$\% 92,04$ \\
Fitik asit; \\
$\% 992,26$ \\
Fitat fosforu; \\
$\% 12$ \\
HKO $\quad \% 13$ \\
Toplam fosfor; \\
\%14
\end{tabular}

TBA uygulanmadan önce her bir yanıt için YYY uygulanarak elde edilen modeldeki $R^{2} \quad$ ve $\quad$ HKO değerlerinin TBA uygulandiktan sonra elde edilen yanita YYY uygulanarak oluşturulan modeldeki $R^{2}$ ve HKO değerlerine oldukça yakın olduğu Tablo 6'dan görülmektedir. $\mathrm{Bu}$ nedenle her bir yanıt için tek tek YYY uygulamak yerine TBA'den elde edilen yanıta YYY uygulanması bu problem için oldukça avantaj sağlamıştır. 


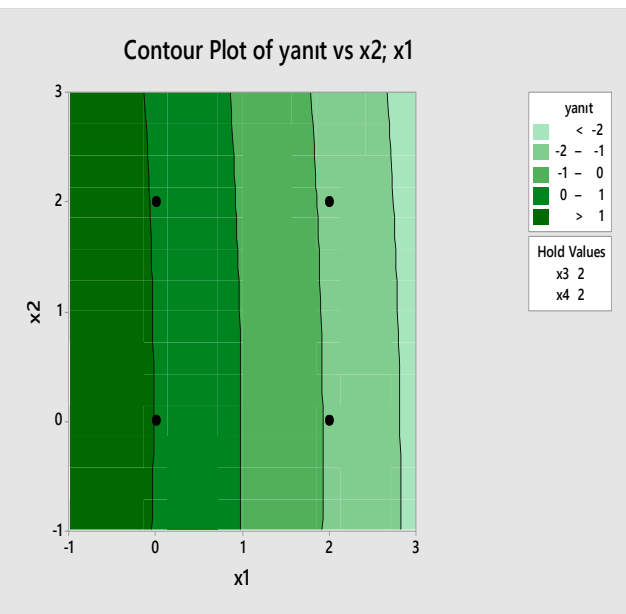

Şekil 3. En büyük en iyidir modeli için kontur grafiği

Surface Plot of yanit vs x2; $x 1$

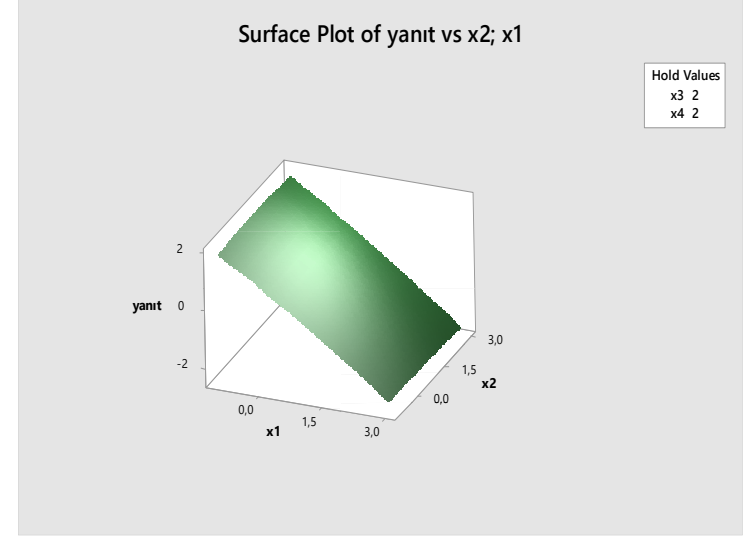

Şekil 4. En büyük en iyidir modeli için yanıt yüzey grafiği

Problemin amacı doğrultusunda olması istenen değerler, en büyük en iyidir modelinde elde edilmiştir. $\mathrm{Bu}$ modelde buğday unu katma oranının yüksek düzeyi seçildiğinde hedeflenen fitik asit miktarı 868.20, fitat fosforu miktarı 244,80, toplam fosfor miktarı 291,50 olacağ 1 Şekil 3 ve Şekil 4'te görülmektedir.

Çalışmada temel bileşenler analizi SPSS 24 paket programı kullanılarak yapılmıştır. Yanıt yüzey yöntemi ise Minitab 17 paket programı kullanılarak yapılmıştır. Deneme modeli rasgele oluşturulmuştur.

\section{Sonuç ve Tartışma}

$\mathrm{Bu}$ çalışmada, 81 tane mısır ekmeği verisi kullanılmıştır. Her bir ekmek bir deney birimi olarak kabul edilmiştir. Mısır ununa farklı oranlarda buğday unu katılarak hazırlanan karışımlara farklı maya, fermantasyon ve pişirme süresi uygulayarak yapılan ekmeklerin fitik asit miktarları, fitat fosforu ve toplam fosfor miktar1 incelenmiştir.

Ekmeğin insan yaşamındaki yeri ve önemi göz önüne alındığında sağlıklı ekmeklerin yapımında istatistiksel analizlerin kullanımı önemlidir. Çoklu yanıtların olduğu bir deneyde her bir yanıtın ayrı ayrı ele alınması problemin çözümünü karmaşık bir hale getirecektir. Yanıt değişkenlerinin bir kısmı veya tamamı nispeten ilişkiliyse, orijinal korelasyonlu yanıt seti, TBA yardımıyla bir veya daha az sayıda ilişkisiz ana bileşene indirgenebilir. Bu çalışmada, TBA kullanılarak çoklu yanıt değişkenlerinin karmaşıklığı en aza indirilmiştir ve YYY kullanılarak değişkenlerin optimizasyonu sağlanmıştır. Yöntemde ilk olarak çoklu yanıt değişkenleri arasındaki korelasyonun varlığına bakılmıştır. Değişkenler arasındaki ilişkiyi ortadan kaldırmak için TBA kullanılmıştır. YYY kullanılarak yeni yanıt değişkeninin amaca uygun olacak şekilde optimizasyonu sağlanmış ve optimum koşullar kontur grafiği ve yanıt yüzey grafiği çizilerek tespit edilmiştir. Çoklu yanitlar, verilerin en yüksek yüzdesini açıklayan temel bileşen skorlariyla tamamlanabilir. Bununla birlikte, seçilen temel bileşen tarafından 81 açıklanan varyansı doğrulamak ve bu bileşendeki skorlar ile temel bileşenler analizinde kullanılan her bir orijinal yanit değişkeni arasındaki korelasyonu doğrulamak çok önemlidir. Açıklanan 
varyans ve korelasyonlar tatmin edici ise, çoklu yanıt yüzey analizi doğru ve güvenilir olacaktır. Temel bileşenler analizi kullanılmadan ve her bir yanıt için yanıt yüzey yöntemi uygulanarak elde edilen modellerin $R^{2}$ ve HKO değerlerinin, temel bileşenler analizinden sonra elde edilen yanıt değişkenine yanıt yüzey yöntemi uygulanarak elde edilen modelin $R^{2}$ ve HKO değerlerine oldukça yakın olduğu görülmekte ve bilgi kaybı olmamaktadır. $\mathrm{Bu}$ nedenle her bir yanıt için tek tek yanıt yüzey yöntemi uygulamak yerine temel bileşenler analizi ve ardından yanıt yüzey yöntemi uygulanması bu problem için oldukça avantaj sağlamıştır. Problemin amac1 doğrultusunda olması istenen değerler, en büyük en iyidir modelinde elde edilmiştir. Bu modelde buğday unu katma oranının yüksek düzeyi seçildiğinde hedeflenen fitik asit miktarı 868.20, fitat fosforu miktarı 244,80, toplam fosfor miktarı 291,50 olarak elde edilmiştir.

G1da sektöründe optimalitenin sağlanmasında klasik YYY'nin artan yanıt sayısıyla meydana gelen çoklu yanıt problemini çözmekte kullanılan yöntemlerden biri olan TBA ile birlikte kullanılmasının sağladığı faydalar vurgulanmıştır. Literatürde bu konu ile ilgili çalışmalar oldukça azdır. Daha kısa sürede daha az madde ile daha iyi sonuçların alınması günümüz şartlarında artık daha da önemli bir hale geldiğinden yanıt yüzey çalışmaları oldukça kullanışlıdır. Yanıt sayısında meydana gelecek bir artma söz konusu olduğunda karşılaşılan güçlüklere bir çözüm olarak TBA yöntemi sunulmuştur. Böylece YYY'nin çoklu yanıtların olduğu durumda disiplinler arası geçişe olanak sağlayan oldukça kullanışlı bir yöntem olduğu vurgulanmıştır.

\section{Kaynaklar}

Bayrak, H., Özkaya, B., Tekindal, M.A. 2010. "Productivity in the first degree ort he optimum point determination of factorial trials: An application", Turkiye Klinikleri Journal of Biostatistics, 2(1), 18-27.

Bilgiçli, N. 2002. "Fitik Asitin Beslenme Açısından Önemi ve Fitik Asit Miktarı Düşürülmüş Gida Üretim Metotları", Selçuk Tarım ve Gıda Bilimleri Dergisi, 16(30), 79-83.

Cheryan, M. 1980. "Phytic Acid Interaction in Food System", Critical Reviews in Food Science and Nutrition, 13(4), 297-335.

Derringer, G., Suich, R. 1980. "Simultaneous optimization of several response variables", Journal of quality technology, 12(4), 214-219.

Díaz-García, J.A., Bashiri, M. 2014. "Multiple response optimisation: An approach from multiobjective stochastic programming", Applied Mathematical Modelling, 38(7-8), 2015-2027.

Ebegil, M., Apaydın, B., Kılıç, D., Bayrak, H. 2017. "The Determination of Optimal Production of Corn Bread Using Response Surface Method and Data Envelopment Analysis", 10th International Statistics Congress, Ankara,164.

Empson, K.L., Labuza, T.P., Graf, E. 1991. "Phytic Acid As a Food Antioxidant", Journal of Food Science, 56(2), 560-563.

Harland, B.F., Harland, D.J. 1980. "Fermentative Reduction of Phytale in Rye, White and Whole Wheat Breads", Cereal Chemistry, 57(3), 226-229. 
Hair, J. F., Black, W.C., Babin, B.J., Anderson, R.E. 2009. "Multivariate Data Analysis", Pearson Prentice Hall.

Khuri, A.I., Conlon, M. 1981. "Simultaneous optimization of multiple responses represented by polynomial regression functions", Technometrics, 23(4), 363-375.

K1lıç, D. 2018. "Faktöriyel Denemeler İçin Yanit Yüzeyi Metodunun Uygulanması", Yüksek Lisans tezi, Gazi Üniversitesi Fen Bilimleri Enstitüsü, Ankara.

Kılıç, D., Bayrak, H., Özkaya, B. 2018. "Mısır Ekmeğindeki Fitik Asit Miktarını Etkileyen Faktörlerin Belirlenmesinde Yanıt Yüzey Yöntemi Yaklaşımı”, Selçuk Üniversitesi Fen Fakültesi Fen Dergisi, 44(2), 121-134.

Knuckles, B.E. 1988. "Effect of Phytate and Other Myoinositol Phosphate Esters on Lipase Activity", Journal of Food Science, 53(1), 250-252.

Koksoy, O. 2005. "Dual response optimization: the desirability approach", International Journal of Industrial Engineering: Theory, Applications and Practice, 12(4), 335-342.

Özkaya, B., Özkaya, H., Duman, B. 2013. "Effects of Yeast Types on Phytic Acid Content of Traditional Corn Bread", The 2nd International Symposium on Traditional Foods From Adriatic to Caucasus, Macedonia, 234.

Pignatiello Jr, J.J. 1993. "Strategies for robust multiresponse quality engineering", IIE transactions, 25(3), 5-15.

Sahu, J., Mohanty, C.P., Mahapatra, S.S. 2013. "A DEA approach for optimization of multiple responses in electrical discharge machining of AISI D2 steel", Procedia Engineering, 51, 585-591.

Shadkam, E., Bijari M. 2015. "The Optimization of bank branches efficiency by means of response surface method and data envelopment analysis: a case of Iran", Journal of Asian finance, Economics and Business, 2(2), 13-18.

Tai, C.Y., Chen, T.S., Wu, M.C. 1992. “An enhanced Taguchi method for optimizing SMT processes", Journal of Electronics Manufacturing, 2(03), 91-100. 